\title{
Biological control of Rhizoctonia solani in tomatoes with Trichoderma harzianum mutants
}

\author{
Jaime Montealegre \\ Departamento de Sanidad Vegetal \\ Facultad de Ciencias Agronómicas \\ Universidad de Chile \\ Casilla 1004, Santiago, Chile
}

\section{Luis Valderrama}

Departamento de Sanidad Vegetal

Facultad de Ciencias Agronómicas

Universidad de Chile

Casilla 1004, Santiago, Chile

\author{
Soledad Sánchez \\ Departamento de Sanidad Vegetal \\ Facultad de Ciencias Agronómicas \\ Universidad de Chile \\ Casilla 1004, Santiago, Chile
}

\section{Rodrigo Herrera}

Departamento de Sanidad Vegetal

Facultad de Ciencias Agronómicas

Universidad de Chile

Casilla 1004, Santiago, Chile

\author{
Ximena Besoain \\ Laboratorio de Fitopatología \\ Facultad de Agronomía \\ Pontificia Universidad Católica de Valparaíso \\ Quillota, Chile \\ Luz María Pérez* \\ Asesorías e Inversiones Biostrategy Limitada \\ Hernando de Aguirre 1372 \\ Providencia, Santiago, Chile \\ E-mail: Biostrategy.perez2@gmail.com
}

Financial support: This research was funded by FONDECYT 1040531-04.

Keywords: bioantagonism, field assays, greenhouse assays, root rot, tomato.

Abbreviations: BCAs: biocontrol agents

cv.: cultivar

cfu: colony forming units

Biocontrol of Rhizoctonia solani in tomatoes cultivated under greenhouse and field conditions was analyzed using the Trichoderma harzianum mutants Th650-NG7, Th11A80.1, Th12A40.1, Th12C40.1 and Th12A10.1 and ThF2-1, respectively. Their innocuousness on tomato cultivars 92.95 and Gondola (greenhouse assays), and on cultivar Fortaleza (field assays) was established. Alginate pellets (1.7 $\mathrm{g}$ pellets/L soil) containing $\mathrm{c} . \mathrm{a} 1 \mathrm{x}$ $10^{5}$ colony forming units (cfu)/g pellet were applied to a soil previously inoculated with $R$. solani at transplant (greenhouse) or to a naturally infected soil (field).
Controls considered parental wild strains, a chemical fungicide and no additions. Th11A 80.1, Th12A10.1 and Th650-NG7 prevented the $100 \%$ mortality of tomato plants cv. 92.95 caused by $R$. solani, and the $40 \%$ mortality in tomato plants cv. Gondola (greenhouse assays). Mortality reduction was reflected in canker level lessening and in plant parameters increases (development, fresh and dry weights). A different degree of susceptibility of tomato plants was observed, being Gondola cv. more resistant than $92.95 \mathrm{cv}$. to infection in a soil previously inoculated with $R$. solani.

*Corresponding author 
Tomato plants of cv. Fortaleza did not show mortality in naturally infected soils (field assays), where the mutant ThF2-1 reduced significantly the canker level caused by R. solani.

$R$. solani is one of the phytopathogens that attack tomatoes cultivated under greenhouse conditions, causing root and crown rot (Latorre, 2004). $R$. solani is controlled using methyl bromide (Apablaza, 2000), a fumigant known for its high toxicity and its degradative effect on the ozone layer (Duniway, 2002).

Fungi of the genus Trichoderma are important biocontrol agents (BCAs) of several soil borne phytopathogens (Benítez et al. 2004). The molecular characterization of several wild isolates has shown a certain degree of polymorphism and the presence of three different ITS lengths (Hermosa et al. 2000) and the secondary metabolites involvement in biocontrol has been recently reviewed (Reino et al. 2008). Trichoderma use different mechanisms for the control of phytopathogens which include mycoparasitism, competition for space and nutrients, secretion of antibiotics and fungal cell wall degrading enzymes (Kubicek et al. 2001; Howell, 2003; Benítez et al. 2004; Harman et al. 2004). In addition, Trichoderma could have a stimulatory effect on plant growth (Naseby et al. 2000) as a result of modification of soil conditions.

The biocontrol by fungal species of the Trichoderma genre, of root and crown rot caused by $R$. solani, are being used as an alternative to chemical fungicides (Papavizas, 1985; Limon et al. 1999; Rey et al. 2001). Nevertheless, the need to improve the positive effect of wild BCAs has prompted the development of different strategies, including those related to increasing the expression and secretion of enzymes such as chitinases and endoglucanases involved in the degradation of the phytopathogen's cell walls. This strategy has resulted in mutant strains with enzyme activities higher than those of their wild-type parents (Limon et al. 1999; Rey et al. 2001, Besoain et al. 2007, Pérez et al. 2007) and where T. harzianum mutant strains have proved to be effective in vivo biocontrol agents of $R$. solani that causes crown and root rot in tomatoes (Pérez et al. 2007). However, their innocuousness on tomato plants and their effectiveness as biocontrol agents on $R$. solani has not yet been tested.

The present work describes these effects under greenhouse and field conditions.

\section{MATERIALS AND METHODS}

\section{Fungal strains}

R. solani strain 618 (AG 4), and five T. harzianum mutants (Th650-NG7, Th11A80.1, Th11C40.1, Th12A.10.1 and ThF2-1) and their corresponding parental strains (Th650,

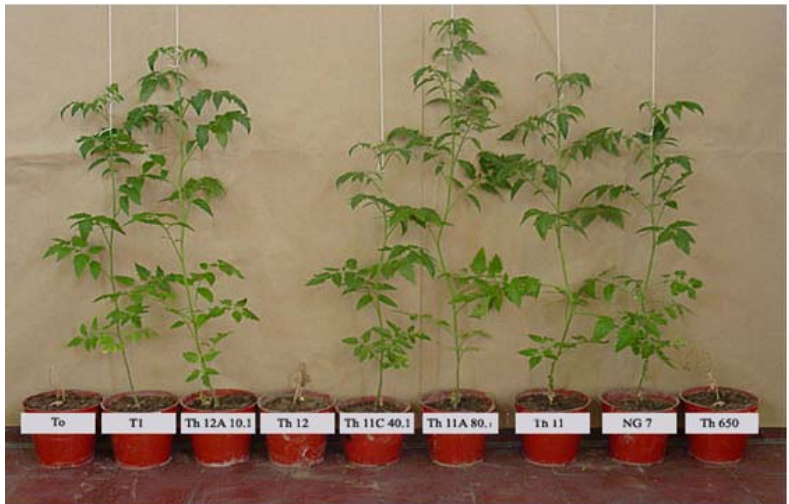

Figure 1. Tomato plants cv 92.95 grown in $2.3 \mathrm{~L}$ pots containing Antumapu soil inoculated with $R$. solani 618 and different treatments. T0: Only $R$. solani, T1: $R$. solani $618+$ pencycuron, NG-7: Th650-NG7. Others correspond to the different $T$. harzianum strains used in treatments.

Th11, Th12, ThV and Th291) were used (Besoain et al. 2007; Montealegre et al. 2007; Pérez et al. 2007).

\section{Tomato plants}

Tomato plants of cultivars (cvs.) 92.95 and Gondola, susceptible to $R$. solani, were used for greenhouse assays and tomato plants of cv. Fortaleza, also susceptible to the phytopathogen, was used for field assays.

\section{Soils}

Soils used were: A) Antumapu Campus (Universidad de Chile, Santiago, Metropolitan Region), and C) Olmué (V Region), Chile. The physical and chemical analysis, performed by the Institute of Agricultural Research - Chile (INIA) of both types of soils showed:

For type A soil (Antumapu): $12.8 \%$ sand, $46.4 \%$ slime and $40.8 \%$ clay; $\mathrm{pH}=7.8$, conductivity $\left(\mathrm{mS} / \mathrm{cm}^{2}\right)=1.6$, organic material $=2.8 \%$, available $\mathrm{N}(\mathrm{mg} / \mathrm{Kg})=63$, available $\mathrm{P}$ $(\mathrm{mg} / \mathrm{Kg})=30$ and available $\mathrm{K}(\mathrm{mg} / \mathrm{Kg})=192$.

For type C soil (Olmué): $42.7 \%$ sand, $35.8 \%$ slime and $21.5 \%$ clay; $\mathrm{pH}=7.1$, conductivity $\left(\mathrm{mS} / \mathrm{cm}^{2}\right)=4.1$, organic material $=3.7 \%$, available $\mathrm{N}(\mathrm{mg} / \mathrm{Kg})=32$, available $\mathrm{P}$ $(\mathrm{mg} / \mathrm{Kg})=200$ and available $\mathrm{K}(\mathrm{mg} / \mathrm{Kg})=580$.

The type A soil was used for greenhouse assays after steam sterilization for $20 \mathrm{~min}$ at $121^{\circ} \mathrm{C}$.

\section{Greenhouse assays: effectiveness of native and mutant Trichoderma strains in the control of $R$. solani in greenhouse tomatoes}

The effectiveness experiments on $R$. solani were run after evaluation of innocuousness of the different $T$. harzianum strains on tomato plants cvs. 92.95 and Gondola, as in Besoain et al. (2007). 
Table 1. Treatments of tomato plants in greenhouse assays.

\begin{tabular}{|c|c|c|c|}
\hline Treatment $^{1}$ & $\begin{array}{c}\text { R. solani (21 g inoculum/ pot; } 8 \times 10^{5} \\
\text { cfu/g) }\end{array}$ & $\begin{array}{l}\text { Chemical fungicide }(0.15 \mathrm{cc} \\
\text { Pencycuron } / \text { pot })^{2}\end{array}$ & $\begin{array}{l}\text { Trichoderma } \\
\text { strain }^{3}\end{array}$ \\
\hline TO & + & No & No \\
\hline $\mathrm{T} 1$ & + & + & No \\
\hline Th650 & + & No & Th650 \\
\hline Th650-NG7 & + & No & Th650-NG7 \\
\hline Th11 & + & No & Th11 \\
\hline Th11A80.1 & + & No & Th11A80.1 \\
\hline Th11C40.1 & + & No & Th11C40.1 \\
\hline Th12 & + & No & Th12 \\
\hline Th12A10.1 & + & No & Th12A10.1 \\
\hline
\end{tabular}

${ }^{1}$ Fungal strain inoculated at seedling transplant (3-5 true leaves).

${ }^{2}$ Fungicide specific for fungi of Rhizoctonia genre, applied to soil as recommended by the manufacturer $(0.15 \mathrm{cc} / \mathrm{pot})$.

${ }^{3}$ Bioantagonists formulated in sodium alginate, were applied to the soil at seedling transplant. Formulations contained: Th650 $\left(4.9 \times 10^{5} \mathrm{cfu} / \mathrm{g}\right)$, Th650-NG7 $\left(5.1 \times 10^{5} \mathrm{cfu} / \mathrm{g}\right)$, Th12 $\left(3.8 \times 10^{5} \mathrm{cfu} / \mathrm{g}\right)$, Th12A10.1 $\left(5.6 \times 10^{5} \mathrm{cfu} / \mathrm{g}\right)$, Th11 $\left(1.2 \times 10^{5} \mathrm{cfu} / \mathrm{g}\right)$, Th11A80.1 $\left(7.9 \times 10^{5} \mathrm{cfu} / \mathrm{g}\right)$ and Th11C40.1 (10.4 × $\left.10^{5} \mathrm{cfu} / \mathrm{g}\right)$.

Once fungal innocuousness was established tomato seedlings of cvs. 92.95 and Gondola were transplanted from speedlings to $2.3 \mathrm{~L}$ pots containing sterile type A soil inoculated with $R$. solani 618 (21.0 g inoculum/pot; 8 × $10^{5}$ colony forming units (cfu)/g inoculum) grown on sterile oat seeds (Santander et al. 2003) to run the treatments shown in Table 1 . The inoculum was introduced close to where the root pan and crown of the plant were going to be placed. Inoculum concentration was established after grounding the oat seeds, and further serial dilutions in selective culture medium (Madigan et al. 2003).

Sodium alginate pellets of the wild or mutant strains of $T$. harzianum innocuous for these tomato cvs. at the concentrations indicated in Table 1, were prepared (Montealegre et al. 2005) and $4 \mathrm{~g} /$ pot of each strain were applied at transplant to the soil as in Besoain et al. (2007). They were mixed with the soil close to where the root pan and crown of the plant were going to be planted. Plants were grown under greenhouse conditions, where soil temperature ranged from $20.9^{\circ} \mathrm{C}$ to $28.6^{\circ} \mathrm{C}$ and watered without fertilizers. Each experimental unit corresponded to one plant of each cultivar per each of the nine treatments, considering five replications. Pots were arranged in a complete random design. Once plants reached fruit set between the fourth and the fifth bunch, they were removed, the potting soil was rinsed from the roots and plants were assessed as follows:

a) Crown canker (area size showing lesions in crown related to stem perimeter), was assessed using the following scale, to establish the disease's degree: 0: $0 \%$ area affected, healthy plant; $1:<1 \%$ area affected, slight disease; $2: 5 \%$ 30\% affected area, moderate disease; 3: 30\% - 60\% area affected, important disease; 4: 60\% - 90\% area affected, severe disease; and 5: > 90\% area affected, dead plant.

b) Root development was evaluated using the following scale: 0: no development, dead plant; 1: poor development, weak plant; 2: moderate development, stable plant; 3: good development, healthy plant; and 4 : very good development, healthy plant.

c) Plant mortality was estimated using crown canker and root development results.

d) Aerial fresh and dry weight, and root fresh weight were assessed by weight.

Measured parameters in weight units were analyzed by ANDEVA, and when significant differences were detected, Tukey's test was used at 5\% significance. Crown canker and root development results were analyzed using the non- 


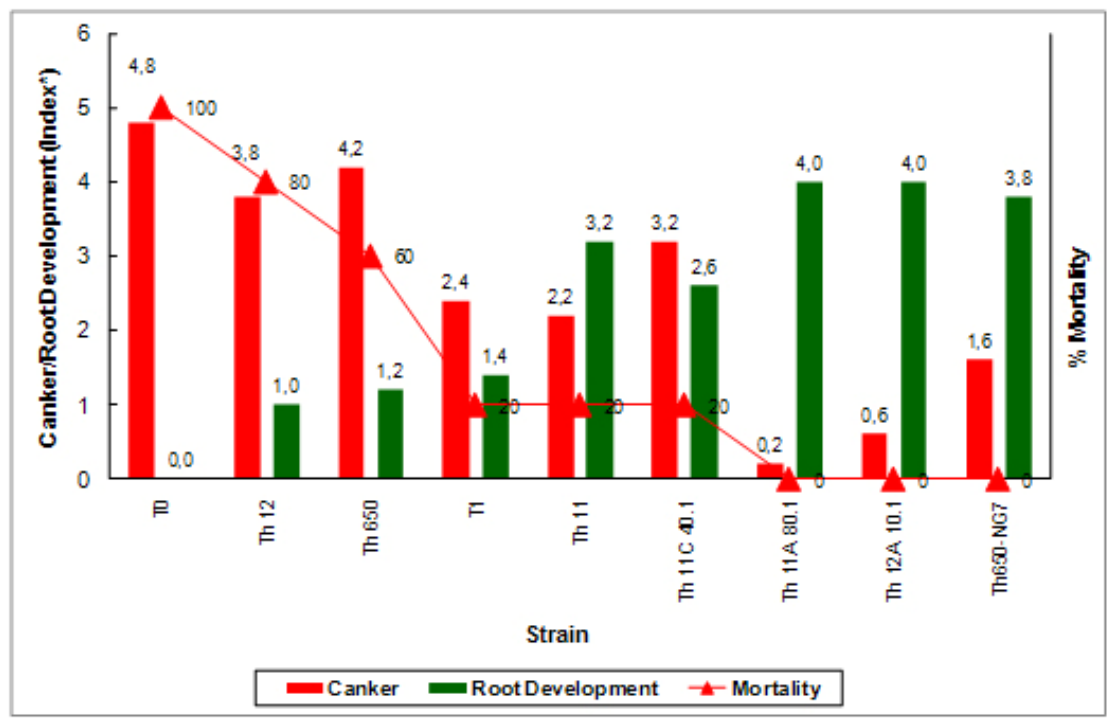

Figure 2. Canker level, Root Development level and \% Mortality of tomato plants cv. 92.95 inoculated with $R$. solani 618: effect of different treatments. T0: without any treatment; T1: pencycuron. ${ }^{*}$ Evaluated using the Kruskal-Wallis non-parametric test, by pair comparisons according to a Mann-Whitney test.

parametric Kruskal-Wallis test, and when significant differences were obtained, the Mann-Whitney pair's comparison was used.

Treatments (Table 1) considering the interaction of each wild or mutant $T$. harzanium strain with $R$. solani 618 , were compared to controls run with $R$. solani 618 (T0) and with $R$. solani 618 plus pencycuron (T1), both in the absence of any $T$. harzianum strain.

\section{Field assays: effectiveness of wild and mutant Trichoderma strains in the control of $R$. solani under field conditions}

Field assays were run under a commercial producer cold greenhouse, located in Olmue (V Region, Chile), using tomato plants cv. Fortaleza, in the season winter - spring. A high incidence of $R$. solani in previous seasons in this field was considered for its selection to run the assay.

Treatments (Table 2) considered the use of two mutant strains: Th12A10.1 and ThF2-1 (Besoain et al. 2007), previously selected as good $R$. solani controllers in vitro (Arias et al. 2006; Montealegre et al. 2007). These strains were formulated as alginate pellets (Montealegre et al. 2005) and their effect was compared with the commercial fungicide Trichonativa (Trichoderma harzianum strain Queule, Trichoderma virens strain Sherwood and Trichoderma parceanamosum strain Trailes), and with the fungicide methyl bromide. An additional control was run with sodium alginate pellets that did not contain any biocontrol agent. The natural Trichoderma spp. population was established before the assay (Williams et al. 2003).
Briefly, 1.7 g pellets/plant, containing Th12A.10.1 (5 x 10 cfu/g pellets) or ThF2-1 (7 x $10^{5} \mathrm{cfu} / \mathrm{g}$ pellets) were applied:

a) To the planting hole in the soil pre-transplanting of tomato plants in one inoculation assays.

b) To the planting hole in the soil pre-transplanting of tomato plants, around the crown 15 days after transplanting and one week before sprout in three inoculation assays.

c) In the watering following the recommendations of the manufacturer $(5 \mathrm{cc} / \mathrm{L})$ in the planting whole pretransplanting and one $\mathrm{L} / \mathrm{Ha}$ in the following inoculations of the commercial product (Bioinsumos Nativa, S. A.).

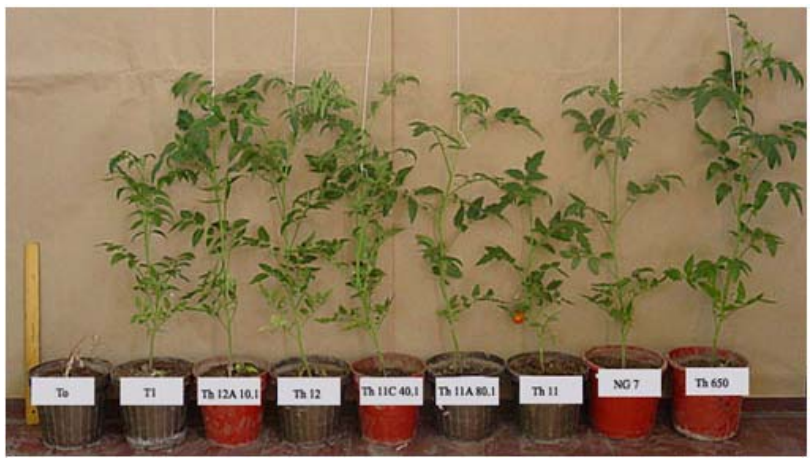

Figure 3. Tomato plants cv Gondola grown in $2.3 \mathrm{~L}$ pots containing Antumapu soil inoculated with $R$. solani and different treatments. T0: Only $R$. solani, T1: $R$. solani 618 + pencycuron, NG7: Th650-NG7. Others correspond to the different $T$. harzianum strains used in treatments. 
Table 2. Treatments of tomato plants in field assays.

\begin{tabular}{|c|c|c|c|c|c|}
\hline Treatment & $\begin{array}{c}\text { Trichoderma } \\
\text { strain pre- } \\
\text { transplanting }\end{array}$ & $\begin{array}{c}\text { Trichoderma } \\
\text { strain 15 days } \\
\text { after } \\
\text { transplanting }\end{array}$ & $\begin{array}{c}\text { Trichoderma one } \\
\text { week before } \\
\text { sprouting }\end{array}$ & $\begin{array}{c}\text { Methyl bromide } \\
\text { pre-transplanting }\end{array}$ & $\begin{array}{c}\text { Alginate pellets without } \\
\text { BCA pre-transplanting }\end{array}$ \\
\hline $\mathrm{T}^{1,4}$ & Th12A10.1 & No & No & No & No \\
\hline $\mathrm{T}^{1,5}$ & ThF2-1 & No & No & No \\
\hline $\mathrm{T}^{2}$ & Th12A10.1 & Th12A10.1 & Th12A10.1 & No & No \\
\hline $\mathrm{T}^{2}$ & ThF2-1 & ThF2-1 & ThF2-1 & No & No \\
\hline $\mathrm{T}^{3}$ & Comm. Product & No & No & No & No \\
\hline $\mathrm{T}^{3}$ & Comm. Product & Comm. Product & Comm. Product & No & No \\
\hline $\mathrm{T} 7$ & No & No & No & Yes & Yes \\
\hline $\mathrm{T} 8$ & No & No & No & No & No \\
\hline
\end{tabular}

$11,7 \mathrm{~g}$ pellets/plant inside the planting whole in pre-transplant inoculation.

${ }^{2} 1,7 \mathrm{~g}$ pellets/plant inside the planting whole in pre-transplant inoculation, $1.7 \mathrm{~g}$ pellets/plant around the crown in each post-transplant inoculation.

${ }^{3}$ The commercial product (Trichonativa) was applied in watering $[5 \mathrm{cc} / \mathrm{L}$, for pre-transplant and $1 \mathrm{~L} / \mathrm{Ha}$ for post-transplant as recommended by the manufacturer, Bioinsumos Nativa S.A.].

${ }^{4} \mathrm{Th} 12 \mathrm{~A} 10.1$ ( $5 \times 10^{5} \mathrm{cfu} / \mathrm{g}$ pellets).

${ }^{5}$ ThF2-1 ( $7 \times 10^{5} \mathrm{cfu} / \mathrm{g}$ pellets).

The experimental unit consisted of ten plants, and each treatment was run in four replicas using a random design. Evaluations considered: a) mortality of plants: 17 days and 31 days after transplant; b) fresh weight: at the end of the crop; c) yield: kg fruit produced up to the third bunch, collected using the collection index recommended by the producer and separating fruits by size (diameter $>67 \mathrm{~mm}$, first quality; $\leq 67>57 \mathrm{~mm}$, second class and $\leq 57 \mathrm{~mm}$, third class); d) damage level caused by $R$. solani: at the end of the crop using the scale mentioned above.

Results were analyzed using ANDEVA, and when significant differences were detected, they were also analyzed by the Tukey's test at $5 \%$ significance. To evaluate canker level and root development, the KruskalWallis non-parametric test was used and when significant differences were obtained, the Mann-Whitney pair's comparison was used.

\section{RESULTS AND DISCUSSION}

\section{Effectiveness of mutants in the control of $R$.} solani in greenhouse tomatoes

All the native and mutant Trichoderma strains tested were innocuous to tomato seedlings and plants of cvs. 92.95 and Gondola confirming the innocuousness of several of these
Trichoderma strains already reported, for experiments run with tomato plants in different conditions (Montealegre et al. 2005; Besoain et al. 2007). Therefore, they were used in greenhouse and field assays to test their biocontrol effect on $R$. solani.

The general effectiveness of wild and mutant strains of $T$. harzianum on the biocontrol of $R$. solani disease on tomato plants cv. 92.95 can be visualized in Figure 1. Control plants (T0), and plants with Th12 and Th650 treatments showed death (100\% mortality, i.e. $0 \%$ survival) and scarce root development, respectively; while the others appear healthy showing different degrees of development, depending on the treatment shown in Table 1. Analysis of plant mortality in cv. 92.95 (Figure 2) shows that the $100 \%$ mortality caused by $R$. solani was reduced to zero by the mutant Trichoderma strains Th650-NG7, Th12A10.1 and Th11A.80.1, while in the presence of Th11C40.1 and Th11 the biocontrol effect was identical to the treatment with the chemical fungicide. The increase in survival caused by the parental strains Th650 and Th12 was lower than the one caused by the corresponding derived mutant. The same mutants showed the lowest canker level (Figure 2) with no significant differences between them, although Th650-NG7 and Th12A.10 were not different from Th11 and with the treatment with pencycuron (T1). In general, the canker level observed in the different treatments, correlate well 


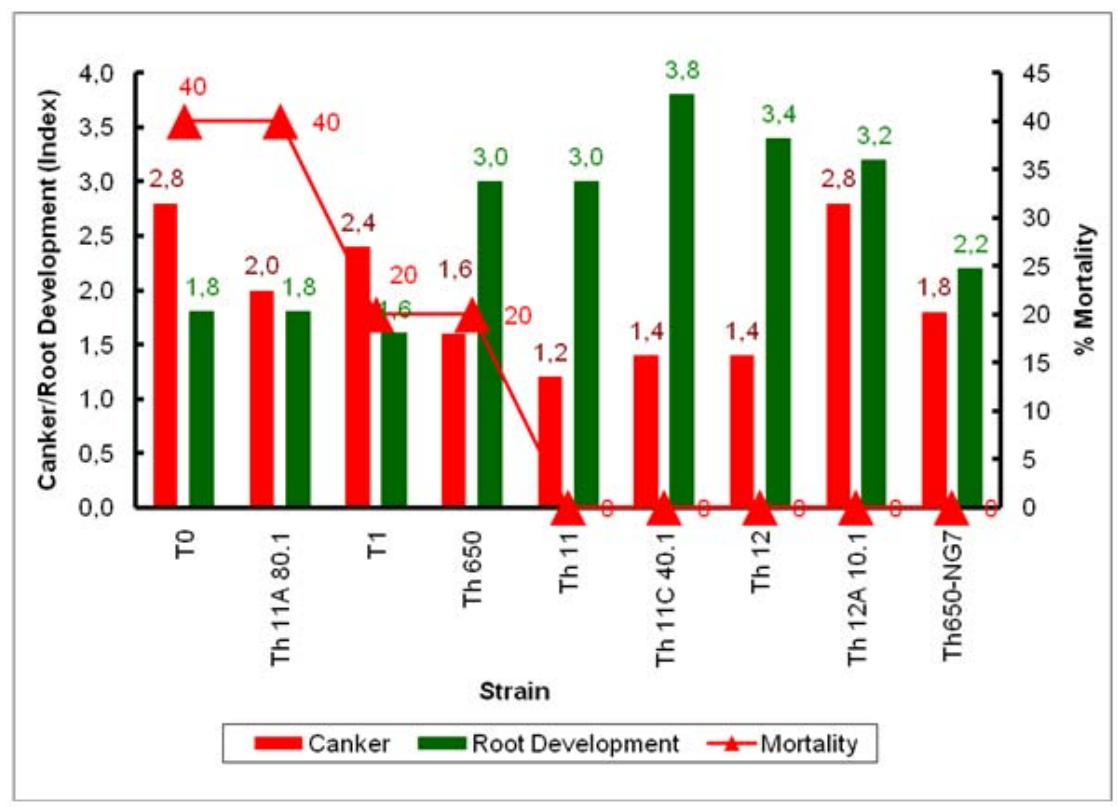

Figure 4. \% Canker level, Root Development level and \% Mortality of tomato plants cv. Gondola inoculated with $R$. solani 618 : effect of different treatments. T0: without treatment; T1: pencycuron. *Evaluated using the Kruskal-Wallis non-parametric test, by pair comparisons according to a Mann-Whitney test.

with results in mortality and those of root development (Figure 2), where treatments with Th650-NG7, Th12A10.1 or Th11A.80.1 resulted in the highest root development. These results suggest that mutants obtained either by chemical or UV treatments, with the exception of Th11C40.1, have improved their biocontrol activity in relation to their parental strains. The obtainment of Trichoderma mutants through different procedures has allowed the obtainment of hyperhydrolytic strains with improved biocontrol activity on R. solani (Rey et al. 2001), of protease overproducing strains with improved biocontrol activity against different pathogens (Szekeres et al. 2004), of salt tolerant strains for the control of $F$. oxysporum (Mohamed and Haggag, 2006) and of pesticidepolyresistant strains (Hatvani et al. 2006), thus supporting the improved biocontrol effect of some of the mutants tested in this work.

The decrease in \% mortality and in canker level and the increase in root development of tomato plants cv. 92.95 caused by Th650-NG7, Th12A10.1 and Th11A.80.1 was also observed in plant fresh weight and root dry weight (Table 3), where treatments with these mutants resulted in the highest values, although Th12A10.1 was the only mutant that caused significant differences in all parameters evaluated. The statistical analysis of results shows that the aerial fresh weight caused by the presence of Th650-NG7 doubles that of Th650, although the latter showed no significant differences with T0. These results do not agree with those previously reported for tomato plants cv. Cal Ace (Santander et al. 2003), where assays were run using soil fumigated with methyl bromide rather than sterile soil.
The best results on tomato plants cv. Cal Ace were obtained with the wild strain Th650, using an inoculum three times lower than the one used in this assay. The lower inoculum used with tomato cv. Cal Ace could explain in part the differences observed among assays, but it cannot be discarded genotypic differences among cultivars in their response to the presence of the same fungal strain or a deleterious effect of the Th650 dose used in this assay (Table 3).

Aerial dry weight of tomato plants cv 92.95 did not differ significantly between treatments except with $\mathrm{T} 0$ and Th12 (Table 3), suggesting that the higher aerial fresh weight obtained after treatment with Th11A80.1 or Th12A10.1 as compared to the other treatments, could reflect a higher content of water rather than to the accumulation of carbon derived compounds.

The smallest root fresh weights obtained in controls (T0) and in Th12 treated tomato plants cv. 92.95, correlate with results on mortality of plants and with the poor root development. Root fresh weights of tomato plants from the other treatments, were consistent with their effect on increasing survival and root development. Therefore, the presence of several Trichoderma strains in soils previously inoculated with $R$. solani 618 are also improving the growth of tomato plants cv. 92.95 in relation to controls run in the absence of any BCA, as has been described in other systems (Naseby et al. 2000).

On the other hand, when behaviour of tomato plants $\mathrm{cv}$. Gondola was compared with those of cv. 92.95, several 
Table 3. Effect of treatments with wild and mutant $T$. harzianum strains on aerial and root fresh weight, and in aerial dry weight of tomato plants cvs. 92.95 and Gondola.

\begin{tabular}{|c|c|c|c|c|c|c|c|c|c|c|c|c|c|c|c|c|c|c|}
\hline \multirow{3}{*}{$\begin{array}{c}\begin{array}{c}\text { Strain used in } \\
\text { treatment }\end{array} \\
\text { Th 12A } 10.1\end{array}$} & \multicolumn{7}{|c|}{$\begin{array}{c}\text { Aerial fresh weight } \\
\text { (g) }\end{array}$} & \multicolumn{6}{|c|}{$\begin{array}{l}\text { Aerial dry weight } \\
\text { (g) }\end{array}$} & \multicolumn{5}{|c|}{$\begin{array}{l}\text { Root fresh weight } \\
\text { (g) }\end{array}$} \\
\hline & \multicolumn{5}{|c|}{ cv. 92.95} & \multicolumn{2}{|c|}{ cv. Gondola } & \multicolumn{4}{|c|}{ cv. 92.95} & \multicolumn{2}{|c|}{ cv. Gondola } & \multicolumn{3}{|c|}{ cv. 92.95} & \multicolumn{2}{|c|}{ cv. Gondola } \\
\hline & 47.34 & a & & & & 35.8 & $a$ & 9.6 & a & & & 4.4 & a & 3.72 & $\mathrm{a}$ & & 3.62 & $\mathrm{a}$ \\
\hline Th 11A 80.1 & 46.48 & a & & & & 31.82 & $a$ & 9.2 & a & $b$ & & 3.82 & $a$ & 4.52 & a & & 2.5 & a \\
\hline Th650-NG 7 & 38.62 & a & $b$ & & & 29.82 & a & 8 & $a$ & $b$ & & 4.24 & $a$ & 3.46 & a & & 3.46 & $\mathrm{a}$ \\
\hline Th 11 & 38.06 & a & $b$ & & & 28.18 & $\mathrm{a}$ & 5.4 & a & $b$ & C & 4.54 & $a$ & 3.68 & $\mathrm{a}$ & & 2.04 & a \\
\hline $\mathrm{T}_{1}{ }^{1}$ & 30.58 & a & $b$ & & & 27.24 & a & 8.2 & a & $b$ & & 5 & $a$ & 1.36 & a & $b$ & 3 & $\mathrm{a}$ \\
\hline Th 11C 40.1 & 27 & a & $b$ & C & & 26.68 & a & 7.1 & a & b & & 3.84 & a & 4.08 & a & & 3.48 & a \\
\hline Th 650 & 18.94 & & $\mathrm{~b}$ & c & & 26.12 & a & 5 & $\mathrm{a}$ & $b$ & C & 5.12 & $\mathrm{a}$ & 1.4 & a & $b$ & 1.92 & $\mathrm{a}$ \\
\hline $\mathrm{T}_{0}^{2}$ & 4.36 & & & c & $d$ & 21.94 & a & 3.8 & & $b$ & c & 4.86 & $\mathrm{a}$ & 0.02 & & $b$ & 2.16 & $\mathrm{a}$ \\
\hline Th 12 & 3.72 & & & & $d$ & 18.88 & $a$ & 0.7 & & & C & 3.52 & $a$ & 0.28 & & $b$ & 2.44 & $a$ \\
\hline
\end{tabular}

Different letters in lines within the same cultivar and plant parameter measured, indicate significant differences after analysis of data by ANDEVA and further analysis by Tukey's test at $\mathrm{p} \leq 0.05 .1 / . \mathrm{T}_{1}\left(R\right.$. solani + Pencycuron $(0.15 \mathrm{cc} / \mathrm{pot}) .{ }^{2} \mathrm{~T}_{0}$ (just $R$. solani 618).

differences were observed: i) T0 was the only Gondola plant where the disease caused by $R$. solani was observed (Figure 3), ii) those inoculated with Th12 or with Th650 showed differences with those of the cv. 92.95, iii) Gondola plants were unaffected by $R$. solani when inoculated with the mentioned wild Trichoderma strains.

Mortality of $100 \%$ caused by $R$. solani in cv. 92.95 was of $40 \%$ in control plants (T0) cv. Gondola (Figure 4), canker level of almost 5 in cv. 92.95 did not reach a level of three in cv. Gondola (Figure 4), and root development of level 1 in cv. 92.95 increased to almost two in cv. Gondola (Figure 4). These results indicate that cv. 92.95 and cv. Gondola differs in their susceptibility towards $R$. solani 618 , most probably due to their genotypic differences because assays were run in the same conditions. A similar behaviour has been observed in different cultivars of Phaseolus vulgaris, where a differential response to $R$. solani was obtained (Gutiérrez et al. 2006). In addition, the less damage caused by $R$. solani in tomato plants cv. Gondola resulted in the absence of significant differences in aerial fresh and dry weight and root fresh weight of plants after treatments. This agrees with results obtained by Le et al. (2003) using tomato plants of the line CL5915-206D, where they did not obtain significant differences between treatments, using $T$. harzianum and $T$. virens, for the control of the sudden death of tomato plants caused by Pythium aphanidermatum.
Treatments of tomato plants cv. Gondola with the wild or mutant Trichoderma strains decreased mortality and canker level, and increased root development (Figure 4) confirming the biocontrol effect of them. Nevertheless, treatment of tomato plants cv. Gondola with the Th11C40.1 mutant resulted in the best parameter values, suggesting that specific interactions may result between cvs. and different Trichoderma strains.

Aerial fresh or dry weight, as well as root fresh weight did not differ between treatments (Table 3), being values similar to those found in cv. 92.95 for most treatments, except those that included the wild strain Th12, Th650 and T0. These results correlate well with mortality values obtained for both tomato cvs. where Th12 and Th650 decreased mortality to only $80 \%$ and $60 \%$, respectively (or in terms of survival, increased only to $20 \%$ and $40 \%$ respectively) in cv. 92.95 (Figure 2), as opposed to the corresponding $0 \%$ and $20 \%$ mortality $(100 \%$ and $80 \%$ survival) observed in cv. Gondola (Figure 4).

\section{Effectiveness of mutants in the control of $R$. solani in tomato plants under field conditions}

Analysis of the Trichoderma spp. in the soil (Williams et al. 2003) showed a concentration of $2,500 \mathrm{cfu} / \mathrm{g}$ soil, which did not contribute to the strain concentration contained in 


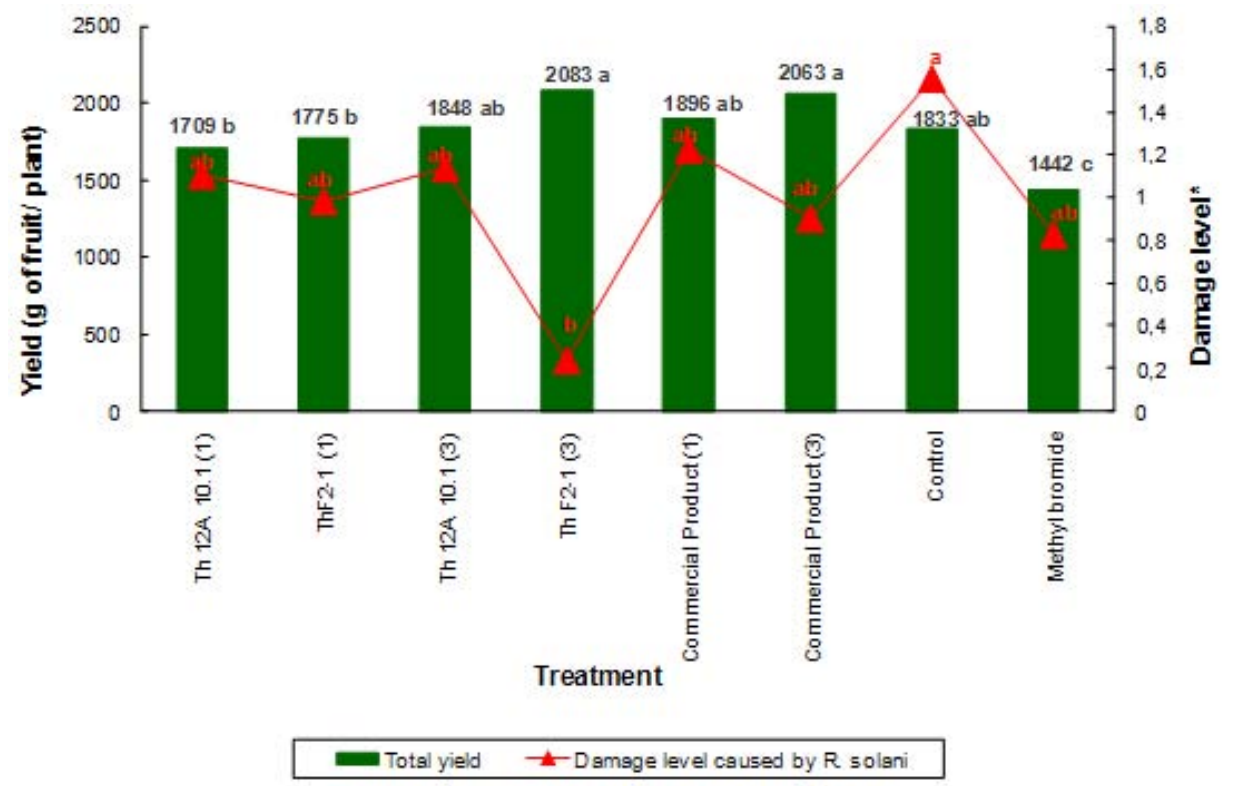

Figure 5. Total yield of tomato fruits and damage level caused by $\boldsymbol{R}$. solani in cv. Fortaleza: effect of different treatments. (1) Applied at pre-transplanting; (3) Applied at pre-transplanting, 15 days after transplanting, one week before sprouting. MeBr: methylbromide, $60 \mathrm{~g} / \mathrm{m} 3$ soil. Different letters indicate significant differences among treatments after variance analysis of results and comparison by the Tukey test at $p \leq 0.05$. *Evaluated using the Kruskal-Wallis non-parametric test, by pair comparisons according to a Mann-Whitney test.

pellets; therefore, results are attributed to the effect of the Trichoderma strains tested in the assay.

No tomato plant mortality was observed in controls and in the different treatments under field conditions, where moderate disease was observed, suggesting that tomato plants cv. Fortaleza used in this assay could be more resistant to $R$. solani attack, as was observed in greenhouse experiments when comparing results between cv. Gondola and cv. 92.95. However, it is possible that the cfu/g pellet used was insufficient to fully control the disease, or that the development and permanence of the strains in the soil was not enough to control the phytopathogen. On the other hand, and looking for tomato cultivars behaviour towards other stress conditions, such as salinity (Al-Karaki, 2000; Reina-Sánchez et al. 2005); zinc (Kaya et al. 2000); weeds (Ngouajio et al. 2001); and water stress (Srinivasa-Rao et al. 2001), it appears not unusual that different tomato cultivars differ in their degree of sensitivity.

Independent of these assumptions, it appears that the Trichoderma strains used in these assays did not have a major preventative effect on the damage caused by $R$. solani, because all plants showed moderate signs of canker crown rot (Results not shown). This suggests that it is possible that specific interactions may be developed between the plant and the biocontrol agent, as was observed for the tomato cv. Cal Ace and Th650 (Santander et al. 2003).

\section{Fresh weight and fruit yield of tomato plants cv. Fortaleza: effect of mutants under field conditions}

Fresh plant weight (Table 4) did not differ between treatments which agrees with results obtained in greenhouse assays for cv. Gondola inoculated with $R$. solani (Table 3), and also with the moderate degree of the disease caused by the phytopathogen in the field experiment.

On the other hand, the use of the two mutant Trichoderma strains did not result in an improved weight of tomato plant roots (Table 4), which neither showed higher weights in the presence of the commercial product. These results are different from those of Pérez et al. (2002) who obtained higher dry weight of tomato plants treated with the BCAs than controls, in assays of tomato plants grown in soil infected by Pyrenochaeta lycopersici where the growth promoting effect was attributed to the presence of the BCAs, as already reported (Naseby et al. 2000).

Fruit yield (Table 4), related to second and third quality fruits did not show differences between treatments, and first quality fruits showed significant differences between treatment with methyl bromide and all the other treatments. As methyl bromide destroys all microorganisms present in soil, independently of their beneficial or damaging activity; it is not unexpected that yield of first quality fruits was lower in this treatment because of the lack of beneficial organisms in the soil that contributes to plant nutrition. On 
Biological control of Rhizoctonia solani in tomatoes with Trichoderma harzianum mutants

Table 4. Mean fresh weight and mean yield of tomato fruits per plant of tomato plants cv. Fortaleza.

\begin{tabular}{|c|c|c|c|c|c|c|c|c|c|c|c|c|}
\hline \multirow[t]{3}{*}{ Strain used in treatment } & \multicolumn{4}{|c|}{ Mean fresh weight } & \multicolumn{8}{|c|}{ Mean field of tomato fruits } \\
\hline & \multicolumn{2}{|c|}{ Total } & \multicolumn{2}{|c|}{ Roots } & \multicolumn{4}{|c|}{$1^{\text {st }}$ quality } & \multicolumn{2}{|c|}{$2^{\text {nd }}$ quality } & \multicolumn{2}{|c|}{$3^{\text {rd }}$ quality } \\
\hline & \multicolumn{4}{|c|}{ (g) } & \multicolumn{8}{|c|}{ (g) } \\
\hline T1 (Th12A10.1) & 1227,2 & a & 71,4 & a & 1.408 & & b & & 252 & a & 20 & a \\
\hline T2 (ThF2-1) & 1366,9 & a & 87,4 & a & 1.548 & a & b & & 213 & a & 14 & a \\
\hline T3 (Th12A10.1) ${ }^{1}$ & 1172,4 & a & 69,5 & a & 1.585 & a & $b$ & & 256 & a & 8 & a \\
\hline T4 $(\text { ThF2-1) })^{1}$ & 1463,4 & a & 91,6 & a & 1.685 & a & $\mathrm{b}$ & & 317 & a & 26 & a \\
\hline T5 (Commercial Product) & 1508,9 & a & 95,4 & a & 1.685 & a & $b$ & & 317 & a & 26 & a \\
\hline T6 (Commercial Product) ${ }^{2}$ & 1441,4 & a & 90,1 & a & 1.825 & a & & & 224 & a & 8 & a \\
\hline T7 (Methyl bromide) & 1302,8 & a & 85,4 & $a$ & 1.281 & & & c & 178 & a & 12 & $\mathrm{a}$ \\
\hline T8 (Control) & 1307,2 & a & 85,8 & $\mathrm{a}$ & 1.745 & a & & & 274 & $\mathrm{a}$ & 14 & $\mathrm{a}$ \\
\hline
\end{tabular}

${ }_{1}^{1} 1,7 \mathrm{~g}$ pellets/plant inside the planting whole in pre-transplant inoculation, $1.7 \mathrm{~g}$ pellets/plant around the crown in each post-transplant inoculation. ${ }^{2}$ The commercial product (Trichonativa) was applied in watering $[5 \mathrm{cc} / \mathrm{L}$, for pre-transplant and $1 \mathrm{~L} / \mathrm{Ha}$ for post-transplant as recommended by the manufacturer, Bioinsumos Nativa S.A.]. Different letters in lines within the same cultivar and plant parameter measured, indicate significant differences after analysis of data by ANDEVA and further analysis by Tukey's test at $p \leq 0.05$.

the other hand, treatments with Trichoderma did not cause significant differences in yield of first quality fruits, suggesting that the presence of BCAs had no effect on this parameter, which in turn was similar to controls where soil contained only the natural microflora.

Damage caused by $R$. solani in tomato plants cv. Fortaleza under field conditions and different treatments (Figure 5) shows that the mutant ThF2-1 strain showed the lowest level of damage as opposed to controls. The damage level caused by $R$. solani on the control tomato plant $\mathrm{cv}$. Fortaleza of 1.58, lower than those obtained for cv. 92.95 of 4.8, and for cv. Gondola of 2.8, suggests that the level of resistance could rely on the genotypic characteristics of each cultivar. The differences in resistance in terms of damage level caused by $R$. solani 618, observed between the tomato $\mathrm{cv}$. tested are also reflected in the differences in plant mortality.

Total tomato fruit yield in plants treated with the mutant ThF2-1 (Figure 5) showed no significant differences with other treatments, suggesting that damage level caused by $R$. solani is not related to this parameter, at least in this tomato cv. On the other hand, the three applications of ThF2-1 improve total tomato fruit yield when compared to the single pre-transplanting application. Results obtained with ThF2-1, a strain obtained through protoplast fusion
(Besoain et al. 2007) agree with the fact that biocontrol strains obtained by these means would contain more and/or more effective biocontrol mechanisms as result of hybridizations between different strains (Howell, 2003).

The lowest fruit yield was obtained with methyl bromide treated plants, most probably due to a phytotoxic effect and/or to an inadequate application of the chemical fungicide.

The effectiveness of all wild and mutant $T$. harzianum strains tested on tomato seeds and seedlings allows us to conclude that these strains may be used both under greenhouse and field conditions. The different mortality of tomato cvs. 92.95 and Gondola observed after inoculation with $R$. solani under greenhouse conditions, and of $\mathrm{cv}$. Fortaleza due to the presence of the phytopathogen in field conditions, suggest that although these cvs. are not resistant to it, they show different degrees of resistance which correlate with the biocontrol effect of the BCAs tested. As this effect was visualized much well in cv. 92.95 that showed the highest mortality caused by $R$. solani, which in turn was prevented by Th650-NG7, Th12A10.1 and Th11A80.1 strains. These Trichoderma strains may be recommended to prevent disease caused by this phytopathogen in this cv 92.95. On the other hand, tomato cvs. Gondola and Fortaleza could improve their yield in the 
presence of some $T$. harzianum strains, although their higher resistance to $R$. solani may be masking the beneficial effect of the BCAs. In addition, the beneficial effect caused by some of the $T$. harzianum strains was better overall than the one caused by pencycuron or by methylbromide, thus being a good alternative to chemical fungicides for the control of $R$. solani. Finally, the use of T. harzianum strains at the field level provides the basis to expand the use of these BCAs to replace chemical fungicides.

\section{REFERENCES}

AL-KARAKI, Ghazi N. Growth, water use efficiency, and sodium and potassium acquisition by tomato cultivars grown under salt stress. Journal of Plant Nutrition, January 2000, vol. 23, no. 1 , p. 1-8.

APABLAZA HIDALGO, Gastón. Patología de cultivos epidemiología y control holístico. Santiago; Ediciones Universidad Católica de Chile. 2000. 347 p. ISBN 956-140561-X.

ARIAS, M.; HERRERA, R.; BESOAIN, X; PÉREZ, L.M. and MONTEALEGRE, J. Evaluación in vitro de mutantes de cepas de Trichoderma para el control de Rhizoctonia solani y Phytophthora nicotianae en tomate. Boletín Micológico, December 2006, vol. 21, no. 3.1, p. 71-75.

BENÍTEZ, Tahía; RINCÓN, Ana M.; LIMÓN, M. Carmen and CODON, Antonio. Bioncontrol mechanisms of Trichoderma strains. International Microbiology, December 2004, vol. 7, no. 4, p. 249-260.

BESOAIN, Ximena; PÉREZ, Luz M.; ARAYA, Antonio; LEFEVER, Llacolén; SANGUINETTI, Melina and MONTEALEGRE, Jaime. New strains obtained after UV treatment and protoplast fusion of native Trichoderma harzianum: their biocontrol effect on Pyrenochaeta lycopersici. Electronic Journal of Biotechnology, October 2007, vol. 10, no. 4, p. 604-617.

DUNIWAY, J.M. Status of chemical alternatives to methyl bromide for pre-plant fumigation of soil. Phytopathology, December 2002, vol. 92, no. 12, p. 1337-1343.

GUTIÉRREZ, Bárbara; GONZÁLEZ, Maria S. and SALIH, Alberto. Caracterización de aislamientos de Rhizoctonia solani (Kühn) que inducen pudriciones radicales en cultivares de caraota (Phaseolus vulgaris L.). Bioagro, 2006, vol. 18, no. 1, p. 63-72.

HARMAN, Gary E.; HOWELL, Charles R.; VITERBO, Ada; CHET, Ilan and LORITO, Mateo. Trichoderma species: opportunistic, avirulent plant symbionts. Nature Reviews Microbiology, January 2004, vol. 2, no. 1, p. 4356.

HATVANI, Lóránt; MANCZINGER, László; KREDICS, László; SZEKERES, András; ANTAL, Zsuzsanna and VÁGVÖLGYI, Csaba. Production of Trichoderma strains with pesticide-polyresistance by mutagenesis and protoplast fusion. Antonie van Leeuwenhoek, May 2006, vol. 89, no. 3-4, p. 387-393.

HERMOSA, M.R.; GRONDONA, I.; ITURRIAGA, E.A.; DIAZ-MINGUEZ, J.M.; CASTRO, C.; MONTE, E. and GARCIA-ACHA, I. Molecular characterization and identification of biocontrol isolates of Trichoderma spp. Applied and Environmental Microbiology, May 2000, vol. 66, no. 5, p. 1890-1898.

HOWELL, C. Mechanisms employed by Trichoderma species in the biologial control of plant diseases: The history and evolutions of current concepts. Plant Disease, January 2003, vol. 87, no. 1, p. 4-10.

KAYA, Cengiz; HIGGS, David and BURTON, Agneta. Plant growth, phosphorus nutrition, and acid phosphatase enzyme activity in three tomato cultivars grown hydroponically at different zinc concentrations. Journal of Plant Nutrition, May 2000, vol. 23, no. 4, p. 569-579.

KUBICEK, C.P.; MACH, R.L.; PETERBAUER, C.K. and LORITO, M. Trichoderma: From genes to biocontrol. Journal of Plant Pathology, 2001, vol. 83, no. 2, p. 11-23.

LATORRE, Bernardo. Enfermedades de las plantas cultivadas. Santiago; Ediciones Universidad Católica de Chile. 2004. 638 p. ISBN 956-14-0756-6.

LE, H.T.T.; BLACK, L.L. and SIKORA, R.A. Evaluation of Trichoderma spp. for biocontrol of tomato sudden death caused by Pythium aphanidermatum following flooding in tropical hot season. Communications in Agricultural and Applied Biological Sciences, 2003, vol. 68, p. 463-474.

LIMON, M. Carmen; PINTOR-TORO, José A. and BENÍTEZ, Tahía. Increased antifungal activity of Trichoderma harzianum transformants that overexpress a 33-kDa chitinase. Phytopathology, March 1999, vol. 89, no. 3, p. 254-261.

MADIGAN, Michael T.; MARTINKO, John M. and PARKER, Jack. Brock: Biología de los Microorganismos. $10^{\text {th }}$ ed. Pearson Educación S.A.; Madrid, 2003. 1096 p. ISBN 8420536792.

MOHAMED, Hassan Abdel-Latif A. and HAGGAG, Wafaa Mohamed. Biocontrol potential of salinity tolerant mutants of Trichoderma harzianum against Fusarium oxysporum. Brazilian Journal of Microbiology, 2006, vol. 37, no. 2, p. 181-191.

MONTEALEGRE, Jaime; HERRERA, Rodrigo; VELÁSQUEZ, Juan Carlos; SILVA, Polyana; BESOAÍN, Ximena and PÉREZ, Luz María. Biocontrol of root and crown rot in tomatoes under greenhouse conditions using Trichoderma harzianum and Paenebacillus lentimorbus. Additional effect of solarization. Electronic Journal of Biotechnology, December 2005, vol. 8, no. 3, p. 249-257. 
MONTEALEGRE, Jaime; VALDERRAMA, Luis; HERRERA, Rodrigo; BESOAÍN, Ximena and PÉREZ, Luz María. Biocontrol of Rhizoctonia solani in tomatoes with Trichoderma harzianum mutants. IOBC/WPRS Bulletin, 2007, vol. 30, no. 6, p. 153-57.

NASEBY, D.C.; PASCUAL, J.A. and LYNCH, J.M. Effect of biocontrol strains of Trichoderma on plant growth, Pythium ultimum populations, soil microbiol communities and soil enzyme activities. Journal of Applied Microbiology, January 2000, vol. 88, no. 1, p. 161-169.

NGOUAJIO, Mathieu; MCGIFFEN, Milton E. and HEMBREE, Kurt J. Tolerance of tomato cultivars to velvetleaf interference. Weed Science, 2001, vol. 49, no. 1, p. 91-98.

PAPAVIZAS, G.C. Trichoderma and Gliocladium: Biology, ecology, and potential for biocontrol. Annual Review of Phytopathology, September 1985, vol. 23, p. 2354.

PÉREZ, Luz María; BESOAÍN, Ximena; REYES, Mauricio; PARDO, Gonzalo and MONTEALEGRE, Jaime. The expression of extracellular fungal cell wall hydrolytic enzymes by different Trichoderma harzianum isolates correlates with their ability to control Pyrenochaeta lycopersici. Biological Research, 2002, vol. 35, no. 3-4, p. 401-410.

PÉREZ, Luz María; POLANCO, Rubén; RIOS, Juan C.; MONTEALEGRE, Jaime; VALDERRAMA, Luis; HERRERA, Rodrigo and BESOAÍN, Ximena. The increase in endochitinases and $\beta$-1,3-glucanases in the mutant Th650-NG7 of the Trichoderma harzianum Th650, improves the biocontrol activity on Rhizoctonia solani infecting tomato. IOBC/wprs Bulletin, 2007, vol. 30, no. 6, p. 135-138.

REINA-SÁNCHEZ, A.; R. ROMERO-ARANDA, R. and CUARTERO, J. Plant water uptake and water use efficiency of greenhouse tomato cultivars irrigated with saline water. Agricultural Water Management, September 2005, vol. 78, no. 1-2, p. 54-66.

REINO, José Luis; GUERRERO, Raul F.; HERNÁNDEZGALÁN, Rosario and COLLADO, Isidro G. Secondary metabolites from species of the biocontrol agent Trichoderma. Phytochemistry Reviews, January 2008, vol. 7, no. 1, p. 89-123.

REY, M.; DELGADO-JARANA, J. and BENÍTEZ, T. Improved antifungal activity of a mutant of Trichoderma harzianum CECT 2413 which produces more extracellular proteins. Applied Microbiology and Biotechnology, May 2001, vol. 55, no. 5, p. 604-608.

SANTANDER, C.; MONTEALEGRE, J. and HERRERA, R. Control biológico de Rhizoctonia solani en tomate en suelos previamente sometidos a solarización y bromuro de metilo. Ciencia e Investigación Agraria, 2003, vol. 30, no. 2, p. 107-112.

SRINIVASA-RAO, N.K.; BHATT, R.M. and SADASHIVA, A.T. Tolerance to water stress in tomato cultivars. Photosynthetica, June 2001, vol. 38, no. 3, p. 465-467.

SZEKERES, András; KREDICS, László; ANTAL, Zsuzsanna; KEVEI, Ferenc and MANCZINGER, László. Isolation and characterization of protease overproducing mutants of Trichoderma harzianum. FEMS Microbiology Letters, April 2004, vol. 233, no. 2, p. 215-222.

WILLIAMS, J.; CLARKSON, J.M.; MILLS, P.R. and COOPER, R.M. A selective medium for quantitative reisolation of Trichoderma harzianum from Agaricus bisporus Compost. Applied and Environmental Microbiology, July 2003, vol. 69, no. 7, p. 4190-4191. 